\title{
Fatty acids inhibit leptin signalling in BRIN-BD11 insulinoma cells
}

\section{P Briscoe, S Hanif ${ }^{\mathbf{1}}, \mathbf{J}$ R S Arch and M Tadayyon}

Department of Vascular Biology, SmithKline Beecham Pharmaceuticals, New Frontiers Science Park, Harlow, Essex, UK

${ }^{1}$ Division of Biochemistry and Molecular Biology, University of Glasgow, Glasgow G12 8QQ, UK

(Requests for offprints should be addressed to M Tadayyon)

\begin{abstract}
The effect of treatment with a $0.03 \%$ fatty acid (FA) cocktail on leptin-receptor-mediated STAT (signal transducers and activators of transcription) activation in the rat insulinoma cell line BRIN-BD11 was investigated. Leptin $(10 \mathrm{nM})$ stimulated the tyrosine phosphorylation of STAT3 and STAT5b. Acute treatment with FAs prevented leptinstimulated STAT3 tyrosine phosphorylation and significantly raised basal STAT5 phosphorylation. A chronic treatment (5 days) of BRIN-BD11 cells with FAs similarly attenuated leptin-stimulated STAT tyrosine phosphorylation. Chronic FA treatment also attenuated prolactin-stimulated STAT5b tyrosine phosphorylation but not
\end{abstract}

interleukin-6-stimulated STAT3 tyrosine phosphorylation, suggesting that the effect is receptor/ ligand specific. TaqMan analysis of gene expression following chronic FA treatment showed neither a decrease in the amount of leptin receptor (Ob-R) mRNA, nor an increase in the negative regulators of STAT signalling, SOCS3 (suppressors of cytokine signalling) or cytokine inducible sequence (CIS). These data demonstrate that FAs modulate leptin and prolactin signalling in $\beta$-cells, implying that high levels of circulating FAs present in obese individuals affect the action of selective cytokines in $\beta$-cell function.

Fournal of Molecular Endocrinology (2001) 26, 145-154

\section{INTRODUCTION}

The adipocyte-derived hormone leptin inhibits food intake and raises energy expenditure through receptors present in the hypothalamic region of the brain (Zhang et al. 1994, Chen et al. 1996, Lee et al. 1996). The leptin receptor (Ob-R) belongs to the class 1 cytokine receptor superfamily (Baumann et al. 1996), which signal through JAKs and STATs (Heinrich et al. 1998). Ob-R is alternatively spliced (Tartaglia et al. 1995), the longest variant, Ob-Rb, being the JAK/STAT signalling and metabolically active form. Leptin activates STAT3 in mouse and rat hypothalamus to induce satiety (Vaisse et al. 1996, McCowen et al. 1998). Leptin-stimulated STAT activation has also been detected in peripheral tissues and cell lines endogenously expressing $\mathrm{Ob}-\mathrm{Rb}$, for example in islets from $o b / o b$ mice lacking endogenous leptin (Seufert et al. 1999), in RINm5F insulinoma cells (Morton et al. 1999), in small-intestine epithelium and in $\mathrm{CaCo} 2$ cells (Morton et al. 1998). Although the shorter leptin receptor isoforms may have signalling capacities, they are unable to activate the JAK/STAT pathway (Bjorbaek et al. 1997).

Leptin levels are elevated in obese individuals (Frederich et al. 1995, Considine et al. 1996), which leads to the proposal that these patients may have reduced leptin sensitivity. Elevated levels of the inhibitors of STAT signalling, a suppressor of cytokine signalling (SOCS) (Starr et al. 1997) and the cytokine inducible sequence (CIS) (Yoshimura et al. 1995), both of which are induced by STATs, have been implicated in obesity-related attenuation of leptin sensitivity. Overexpression of $\mathrm{Ob}-\mathrm{Rb}$ and SOCS3 in Chinese hamster ovary $(\mathrm{CHO})$ or COS-1 cells and of CIS in RINm5F cells was shown to inhibit leptin signalling (Bjorbaek et al. 1998, Emilsson et al. 1999). In vitro leptin stimulates SOCS3 mRNA and protein expression in $\mathrm{CHO}$ cells overexpressing Ob-Rb (Bjorbaek et al. 1999), and in vivo peripheral administration of leptin for $2 \mathrm{~h}$ raises the SOCS3 level in the hypothalamus of the $o b / o b$ mouse (Bjorbaek et al. 1998). 
Of all of the peripheral tissues, it is total pancreas that has the highest proportion of $\mathrm{Ob}-\mathrm{Rb}$ relative to Ob-Ra (Ghilardi et al. 1996). Leptin suppresses insulin release from pancreatic islets of $o b / o b$ mice (Emilsson et al. 1997). Inhibitory effects of leptin on insulin secretion from insulinoma cells have also been reported, e.g. in RINm5F and $\beta$ TC6 cells (Kulkarni et al. 1997, Zhao et al. 1998). Leptin also stimulates cell proliferation in insulinoma cells (Islam et al. 1997, Tanabe et al. 1997) and raises fatty acid (FA) oxidation and mRNA for enzymes involved in FA oxidation, thus lowering triglyceride content (Zhou et al. 1997, Shimabukuro et al. 1997).

FAs have been found to affect $\beta$-cell function through a number of mechanisms (Unger 1995). Studies in the pre-diabetic obese Zucker diabetic fatty $(\mathrm{ZDF})$ rat, which is leptin insensitive because of a mutation in $\mathrm{Ob}-\mathrm{Rb}$, have shown that the early build up of $\beta$-cell triglyceride, due to the high levels of free FAs and increased lipogenesis (Lee et al. 1997), may contribute to the subsequent onset of early diabetic symptoms and eventual $\beta$-cell failure in this animal (Lee et al. 1994, 1997, Zhou \& Grill 1994). As leptin is essential for regulation of $\beta$-cell FA metabolism, obese individuals having high levels of circulating FAs may be prone to developing $\beta$-cell defects if leptin sensitivity is compromised. Although FAs have been reported to bind to leptin, the effects on downstream signalling pathways have not been determined (Campbell et al. 1998, Hidaka et al. 1999). We have therefore investigated whether FAs can influence leptinreceptor-mediated STAT activation in the insulinoma cell line BRIN-BD11 and whether changes in $\mathrm{Ob}-\mathrm{Rb}, \mathrm{SOCS} 3$ or CIS might be involved in this process.

\section{MATERIALS AND METHODS}

\section{Cell culture}

BRIN-BD11 cells were a gift from Professor P Flatt (Coleraine, N. Ireland). Cells were maintained in RPMI-1640 medium (Gibco BRL, Paisley, UK) supplemented with $10 \%(\mathrm{v} / \mathrm{v})$ foetal bovine serum (FBS), $2 \mathrm{mM}$ glutamine and $5 \mathrm{mM}$ glucose at $37^{\circ} \mathrm{C}$ in $5 \% \mathrm{CO}_{2}$. For chronic FA treatment studies, cells were seeded at $4 \times 10^{5}$ cells $/ 25-\mathrm{cm}^{2}$ flask in medium containing 2\% FA-free BSA (Sigma Chemical Co., Gillingham, Kent, UK) and $0.03 \%$ FA mixture comprising methyl esters of myristic acid (11.8\%), palmitic acid $(23 \cdot 6 \%)$, palmitoleic acid $(6 \cdot 9 \%)$, stearic acid $(13 \cdot 1 \%)$, oleic acid $(44 \cdot 6 \%)$ (Sigma Chemical Co.) or vehicle $(0 \cdot 045 \%$ ethanol). After $24 \mathrm{~h}$, cells were rendered quiescent in medium containing $2 \% \mathrm{BSA}, 0.5 \% \mathrm{FBS}$ and $0.03 \% \mathrm{FAs}$ or vehicle control. For acute FA studies, cells were pretreated for 5 days exactly as described above for control cells.

\section{TaqMan analysis of leptin-receptor expression}

Complementary DNA-specific $5^{\prime}$ nuclease assays for $\mathrm{Ob}-\mathrm{Ra}$ and $\mathrm{Ob}-\mathrm{Rb}$ were designed using Primer Express software, (PE Applied Biosystems, Warrington, UK). Primers (Genosys, Cambridge, $\mathrm{UK}$ ) and probes (PE Applied Biosystems) were as follows: Ob-Ra; forward primer 5'-TGTTTTGG GACGATGTTCCA-3', reverse primer 5'-GATA CTTCAAAGAGTGTCCGCTCTC-3', probe 5'CAAGAATTGTTCCTGGGCACAAGGACTTA ATT-3', Ob-Rb; forward primer 5'-TGTTT TGGGACGATGT TCCA-3', reverse primer $5^{\prime}$ AAAGATGCTCAAATGTTTCAGGC-3', probe 5'-CAAGAATTGTTCCTGGGCACAAGGACT

TAATT-3'. TaqMan assays were performed essentially as described previously (Overbergh et al. 1999). TaqMan utilises a gene-specific probe containing both fluorescent and quencher tags, which hybridise to the cDNA between the two PCR primers. As PCR proceeds, the $5^{\prime}$ nuclease activity of the Taq polymerase cleaves the probe, releasing the tag such that the fluorescence is proportional to the amount of cDNA present. The relative quantity of a specific gene transcript present in a sample is determined by comparing the signal from a sample with that from a standard curve obtained from cDNA from rat-brain poly $\mathrm{A}^{+}$RNA (Clontech, Basingstoke, Hants, UK).

\section{Preparation of whole-cell lysates, and Western blotting}

Cells were treated in serum-free medium containing $0 \cdot 1 \% \mathrm{BSA}$ and $10 \mathrm{nM}$ murine leptin (Al-Barazanji et al. 1997), $1 \mathrm{nM}$ human prolactin (Sigma), $1 \mathrm{nM}$ murine interleukin-6 (IL-6) (R\&D Systems, Abingdon, UK) or PBS (Gibco BRL) as a control. For acute FA treatments, stimulations were performed in the presence or absence of $0.03 \%$ FAs. After treatment, cells were washed with ice-cold PBS containing $1 \mathrm{mM} \quad \mathrm{Na}_{3} \mathrm{VO}_{4}$. Cells were lysed in buffer containing $50 \mathrm{mM}$ Tris $(\mathrm{pH}$ 7.5), $150 \mathrm{mM} \mathrm{NaCl}, 1 \mathrm{mM}$ EGTA, $2 \mathrm{mM}$ EDTA, 1\% IGEPAL detergent (Sigma Chemical Co.), $100 \mathrm{mM} \mathrm{NaF}, 10 \mathrm{mM} \mathrm{Na}_{4} \mathrm{P}_{2} \mathrm{O}_{7}, 1 \mathrm{mM} \mathrm{Na} \mathrm{VO}_{4}$ and a protease cocktail inhibitor tablet (Boehringer Mannheim, Germany). Cell lysates were centrifuged for $20 \mathrm{~min}$ at $14000 \mathrm{~g}$ and the resulting supernatant was snap-frozen in liquid $\mathrm{N}_{2}$ and stored at $-80{ }^{\circ} \mathrm{C}$. The protein concentration 
was determined using the Bio-Rad protein assay kit (Bio-Rad Laboratories, Hemel Hempstead, Herts, UK).

Immunoprecipitations were performed overnight using $0 \cdot 4-1 \mathrm{mg}$ fresh lysate, $1 \mu \mathrm{g}$ polyclonal anti-STAT3 $(\mathrm{C}-20)$ or polyclonal anti-STAT5b (C-17) antibody, with $40 \mu$ of a $25 \%$ slurry of protein A/agarose (all from Santa Cruz Biotechnology, Inc., Santa Cruz, CA, USA). Immunoprecipitations were washed with buffer containing $50 \mathrm{mM}$ Tris (pH 7.5), $150 \mathrm{mM} \mathrm{NaCl}$ and $1 \mathrm{mM} \mathrm{Na}_{3} \mathrm{VO}_{4}$, before denaturation at $90{ }^{\circ} \mathrm{C}$ with $2 \times$ Novex sample buffer (Invitrogen, Groningen, The Netherlands). Immunoprecipitates were subjected to SDS-PAGE on Novex $4-12 \%$ Bis-Tris polyacrylamide gels (Invitrogen) and transferred to PVDF membrane (Millipore, Watford, UK). Membranes were blocked and incubated with polyclonal antiphosphoSTAT3 antibody (New England Biolabs, Hitchin, Herts, UK) or with monoclonal antiphosphoSTAT5 antibodies (Upstate Biotechnology, Lake Placid, NJ, USA), then subjected to detection with anti-mouse or anti-rabbit immunoglobulin $G$ secondary alkaline phosphatase-conjugated antibodies (Amersham Pharmacia Biotech, Amersham, Bucks, UK). Blots were exposed to an enhanced chemi-fluorescence (ECF) substrate (Amersham Pharmacia Biotech) and the STAT phosphorylation was quantified, using the fluorescent signal, on a STORM system (Amersham Pharmacia Biotech). In order to normalise STAT phosphorylation to the amount of STAT protein, blots were stripped and reprobed with anti-STAT3 or anti-STAT5b antibodies.

\section{Statistical analysis}

Results are expressed as means \pm s.E.M. For clarity, one experiment that is representative of three is shown. Chemi-fluorescence data from Western blots from three independent experiments were pooled and analysed by 2-way ANOVA, using statistica, $P<0.05$ being considered statistically significant.

\section{RESULTS AND DISCUSSION}

\section{BRIN-BD11 insulinoma cells express long and short leptin-receptor isoforms}

RT-PCR was used to study leptin-receptor expression in the glucose-responsive BRIN-BD11 cells (fusions between rat $\beta$-cells and RINm5F cells) (McClenaghan et al. 1996). Both Ob-Ra and Ob-Rb were found to be expressed (Fig. 1A) and co-migrated with $\mathrm{Ob}-\mathrm{Ra}$ and $\mathrm{Ob}-\mathrm{Rb}$ present in rat hypothalamus. Hybridisation to an internal TaqMan probe confirmed the identities of the products (Fig. 1B).

\section{Leptin stimulates tyrosine phosphorylation of STAT3 and STAT5}

We set out to examine if FAs affect immediate leptin-receptor-mediated signalling; we used BRIN-BD11 cells as a model system, as they express $\mathrm{Ob}-\mathrm{Rb}$ and proliferate in response to leptin (0.01-10 nM; data not shown), thus demonstrating functional responsiveness. Activation of STATs was determined by using the ECF system to quantify tyrosine phosphorylation of the proteins in immunoprecipitates from whole-cell lysates. Leptin $(10 \mathrm{nM})$ elicited significant increases in tyrosine phosphorylation of both STAT3 (Fig. 2A; 2-way ANOVA, $\mathrm{F}=9 \cdot 7, \mathrm{df}=10, \quad P<0 \cdot 05)$ and STAT5b (Fig. 2B; 2-way ANOVA, $\mathrm{F}=23 \cdot 8, \mathrm{df}=12, P<0 \cdot 01$ ) after $30 \mathrm{~min}$ stimulation. Although the tyrosine phosphorylation of STAT proteins by leptin in BRIN-BD11 cells was small $(135 \%$ of control for STAT3 and $178 \%$ of control for STAT5, Fig. 2), this response was reproducible and significant over several experiments. No changes in STAT3 or STAT5b tyrosine phosphorylation were observed after 15-min or 60-min treatments (data not shown), indicating the transient nature of leptin-stimulated STAT phosphorylation.

\section{Acute FA treatment inhibits leptin-stimulated STAT tyrosine phosphorylation}

Initial experiments in which FAs were added directly with leptin to the cells demonstrated that this acute treatment was sufficient to block leptin-stimulated increases in STAT tyrosine phosphorylation (Fig. 2). The mechanisms behind the effect of FAs on STAT3 phosphorylation versus STAT5 phosphorylation appear to be different; although there was no significant effect of FAs on basal STAT3 tyrosine phosphorylation, in the same experiment FAs significantly elevated basal STAT5 tyrosine phosphorylation $162 \%$ above control treatments (2-way ANOVA, F=37.7 df=12, $P<0 \cdot 01$ ) (Fig. 2B). Paradoxically, in the presence of FAs, $10 \mathrm{nM}$ leptin produced a significant (62\%) decrease in STAT5b tyrosine phosphorylation below basal levels (2-way ANOVA, $\mathrm{F}=12 \cdot 62, \mathrm{df}=12, P<0 \cdot 01)$. These experiments therefore suggest that the presence of FAs can alter leptin signalling and therefore the action of leptin in BRIN-BD11 cells. 


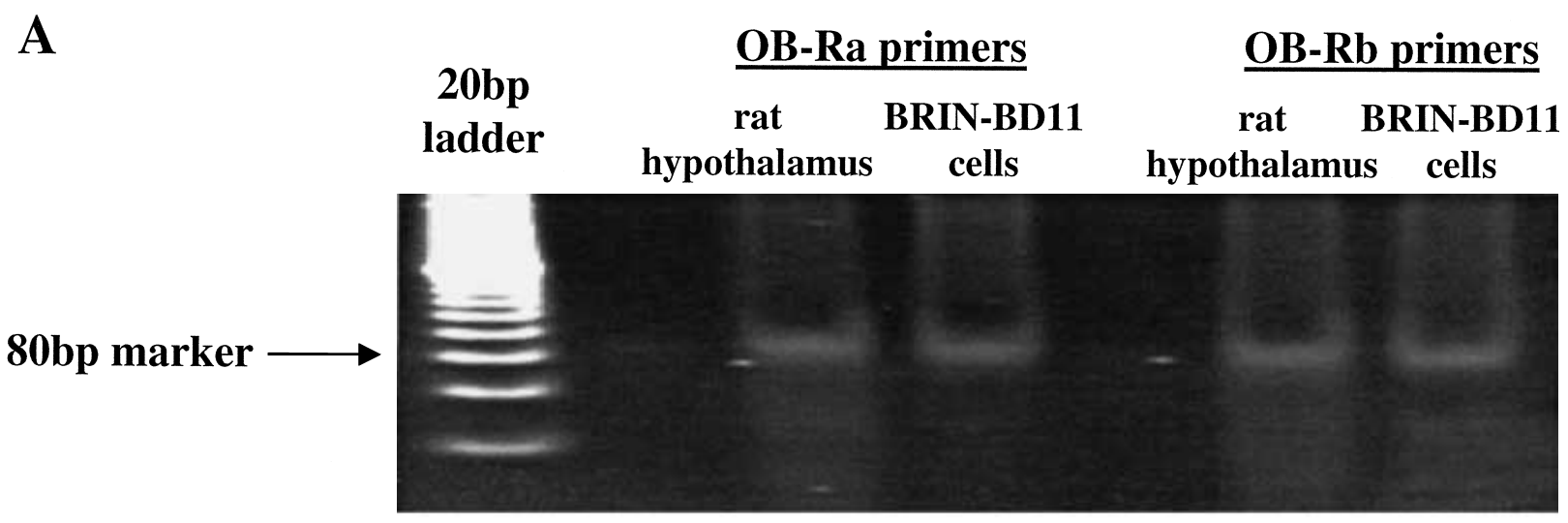

B

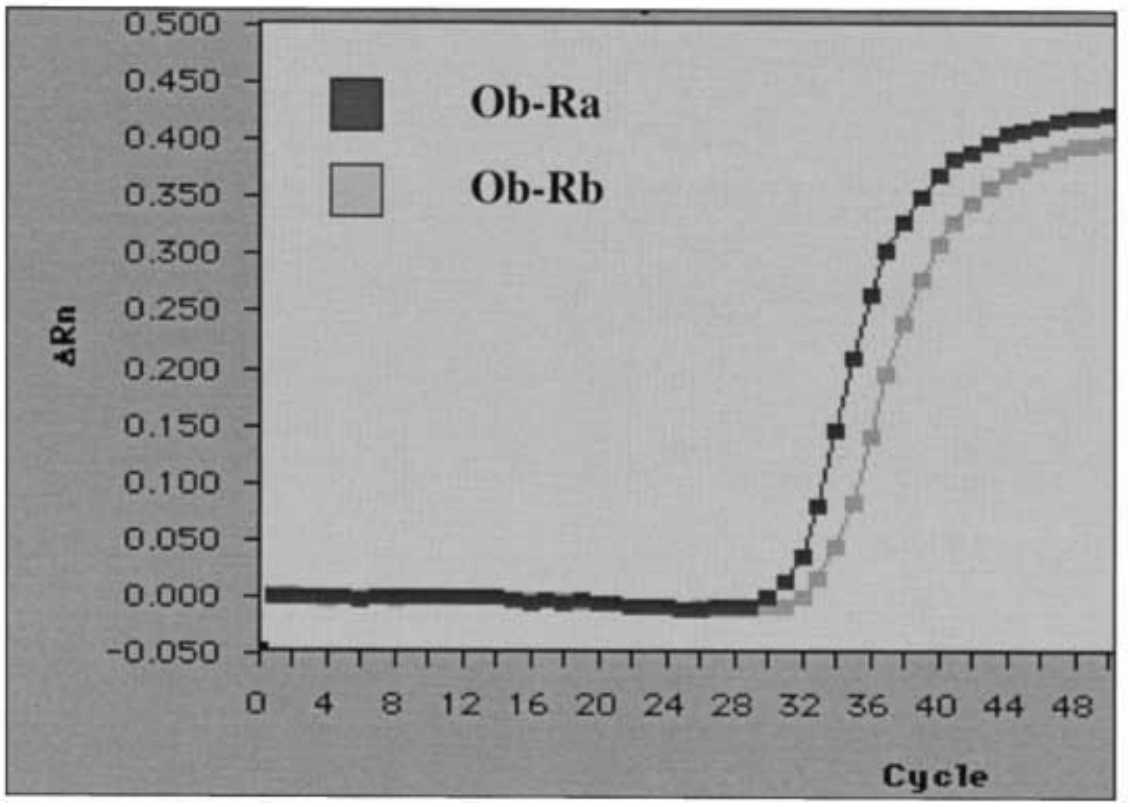

FIGURE 1. Expression of Ob-Rb and Ob-Ra in BRIN-BD11 cells. RT-PCR was employed to detect mRNA for the short and long leptin-receptor isoforms, using specific primers in rat hypothalamus and BRIN-BD11 cells.

(A) Amplified PCR products detected by ethidium bromide staining of a $6 \%$ polyacrylamide gel. (B) Representative TaqMan amplification plot with leptin-receptor-specific probe.

It is possible that acute FA treatment may affect negative regulators of STAT activity, but such an event must be rapid, occurring independently of transcription. The constitutively present cytosolic tyrosine phosphatase SHP-2 (SH2-containing phosphatase) is activated by leptin, becoming bound to $\mathrm{Ob}-\mathrm{Rb}$ after JAK2-mediated tyrosine phosphorylation of the receptor ( $\mathrm{Li} \&$ Friedman 1999). Experiments performed in cells containing mutant $\mathrm{Ob}-\mathrm{Rb}$ unable to bind SHP-2 $\left(\mathrm{Tyr}^{985}\right)$ and endogenous SHP-2 have shown that leptinstimulated binding of SHP-2 to Ob-Rb does not modulate STAT3 tyrosine phosphorylation (Carpenter et al. 1998, Banks et al. 2000), nor was basal STAT3 phosphorylation affected. It seems unlikely, therefore, that acute FA treatment would alter either basal or leptin-stimulated STAT tyrosine phosphorylation through an effect on SHP-2 activity alone. Although the mechanism behind the leptin-mediated suppression of STAT5 tyrosine phosphorylation thus remains to be determined, it is possible that it may reflect opposite actions of leptin and FAs on currently undefined regulators of STAT5 phosphorylation. 

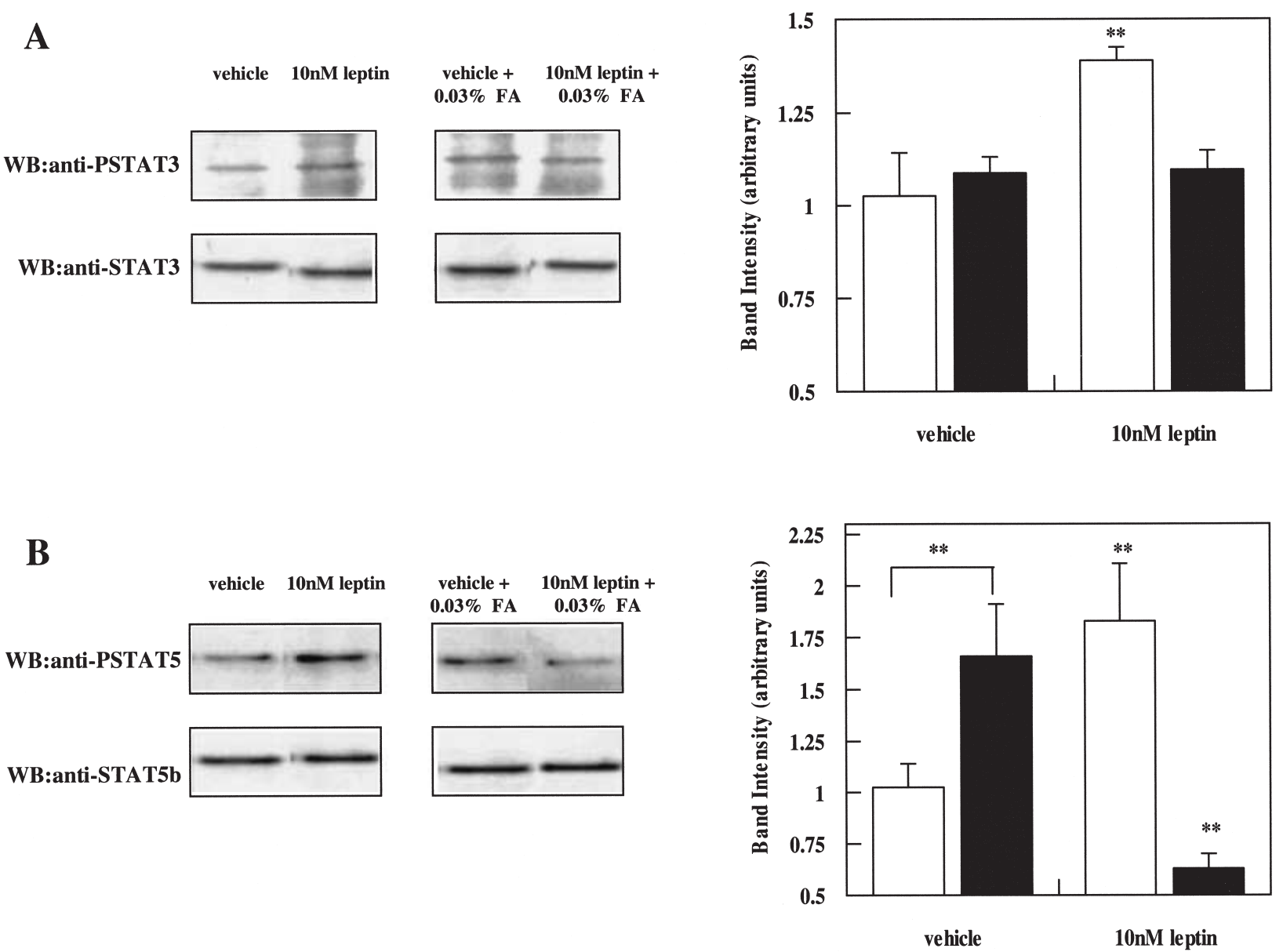

FIGURE 2. Acute FA treatment inhibits leptin-stimulated STAT3 tyrosine phosphorylation. BRIN-BD11 cells were treated with $10 \mathrm{nM}$ leptin or vehicle for $30 \mathrm{~min}$ in the presence or absence of $0.03 \%$ FAs and $2 \%$ BSA. STAT3 (A) or STAT5 (B) immunoprecipitates from whole-cell lysates were Western-blotted (WB) with (A) anti-phosphoSTAT3-specific antibody (anti-PSTAT3), stripped and then reprobed with anti-STAT3 antibody, or (B) anti-phosphoSTAT5-specific antibody (anti-PSTAT5), stripped and then reprobed with anti-STAT5 antibody. Phosphorylation was quantified by ECF and normalised to the levels of STAT protein present. Results are expressed as means \pm s.E.M. $(n=3)$ and are from one experiment representative of three. $\square$, Vehicle; $\square, 0 \cdot 03 \%$ FAs. $* * P<0 \cdot 01$.

\section{Inhibition of leptin-stimulated STAT tyrosine phosphorylation following chronic FA treatment}

In order to study the more chronic effects of FA treatment on BRIN-BD11 cells, 5 day pretreatments with FAs were performed. This was followed by an acute $30 \mathrm{~min}$ treatment with $10 \mathrm{nM}$ leptin (stimulations were performed in the absence of FAs). Chronic FA pretreatment of cells prevented the leptin-mediated increase in both STAT3 and STAT5b tyrosine phosphorylation (Fig. 3). Similarly, chronic FA treatment prevented leptinstimulated DNA binding of STAT3 or STAT5, as determined by electromobility shift assays (EMSAs) (data not shown). In contrast to acute treatment, chronic FA treatment did not significantly alter basal levels of STAT3 or STAT5 tyrosine phosphorylation.

The observed effects of the 5 day FA pretreatment on BRIN-BD11 cells did not appear to be due to losses in cell viability. The FA mixture used in our experiments contained a total of $1 \mathrm{mM} \mathrm{FAs,} \mathrm{comprising} \mathrm{approximately} 250 \mu \mathrm{M}$ palmitate and $440 \mu \mathrm{M}$ oleate. This FA mix appeared to have a proliferative effect over the 5 day period of treatment in BRIN-BD11 cells, more protein typically being recovered from cells treated with FAs than those treated with vehicle. In support of this finding, normal islets cultured 


\section{A}

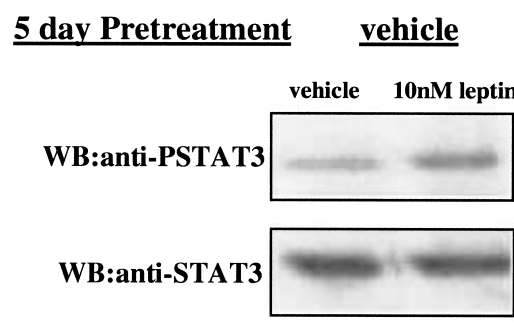

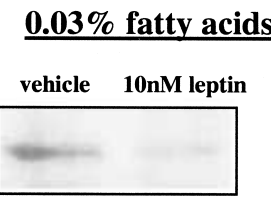

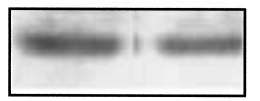

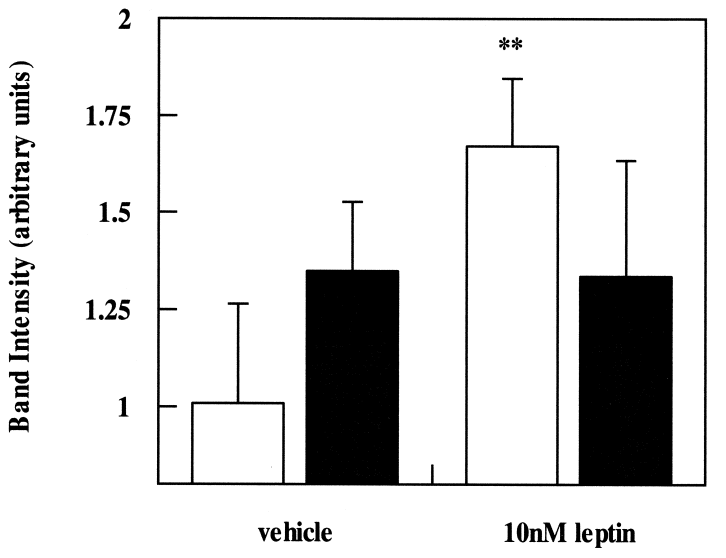

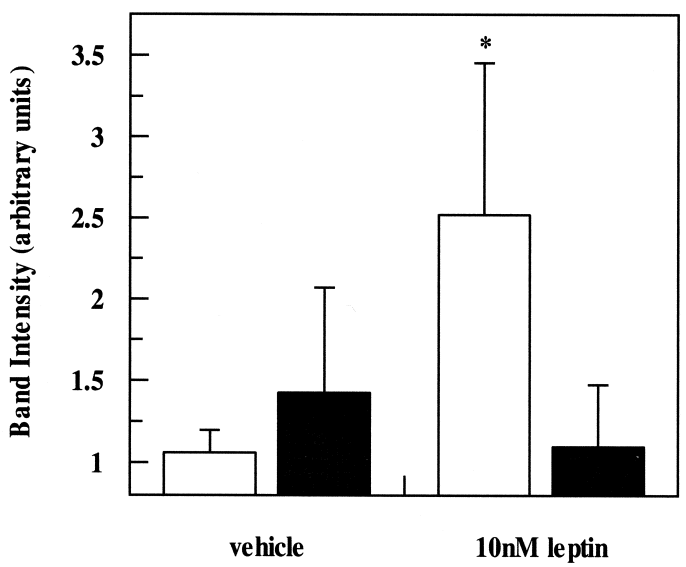

10nM leptin
B

\section{$\underline{5 \text { day Pretreatment }}$ \\ vehicle vehicle 10nM leptin}

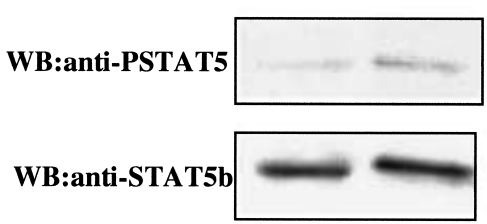

0.03\% fatty acids vehicle 10nM leptin
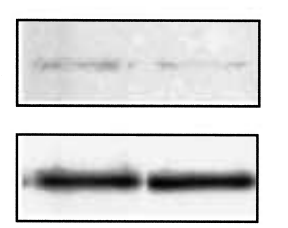

FIGURE 3. Effect of chronic FA treatment on leptin-stimulated STAT3 tyrosine phosphorylation. BRIN-BD11 cells were treated with $10 \mathrm{nM}$ leptin or vehicle for $30 \mathrm{~min}$ after chronic FA or vehicle treatment of cells. STAT3 (A) or STAT5 (B) immunoprecipitates were Western-blotted (WB) with (A) anti-phosphoSTAT3-specific antibody (anti-PSTAT3), stripped and then reprobed with anti-STAT3 antibody, or (B) anti-phosphoSTAT5-specific antibody (anti-PSTAT5), stripped and then reprobed with anti-STAT5 antibody. Phosphorylation was quantified by ECF and normalised to the levels of STAT protein present. Results are expressed as means \pm S.E.M. $(n=3)$ and are from one representative experiment of three. $\square$, Vehicle; $\mathbf{\square}, 0 \cdot 03 \%$ FAs. Analysis, by 2 -way ANOVA, of pooled data from three independent experiments showed that in cells pretreated for 5 days with vehicle, a 30 min treatment with $10 \mathrm{nM}$ leptin elicited a significant increase in tyrosine phosphorylation of STAT3 $(\mathrm{F}=9 \cdot 3, \mathrm{df}=12, * P<0 \cdot 05$, $* * P<0 \cdot 01)$ and STAT5 $(\mathrm{F}=6 \cdot 4, \mathrm{df}=12 * P<0 \cdot 05)$.

for 7 days in $2 \mathrm{mM}$ FAs oleate:palmitate (2:1) showed a $3 \cdot 2$-fold increase in bromodeoxyuridine incorporation (Milburn et al. 1995). Moreover, oleate was able to stimulate c-fos expression and cell proliferation of INS-1 cells (Roche et al. 1999).

\section{Effect of chronic FA treatment on IL-6- and prolactin-stimulated STAT tyrosine phosphorylation}

In order to determine whether the effects of chronic FA treatment were limited to leptin-receptor- mediated events or whether other cytokine receptors, also signalling through the JAK-STAT pathway, were affected, the activation of STAT3 by IL-6 and that of STAT5 by prolactin were examined. Incubation of islets with IL- 6 has been shown to inhibit glucose-stimulated insulin secretion from rat islets (Southern et al. 1990). IL-6 is also an activator of STAT3 in many different cell types (Zhong et al. 1994, Heinrich et al. 1998). As shown in Fig. 4A, IL-6 stimulated an increase in STAT3 tyrosine phosphorylation (2-way ANOVA from three independent experiments: $\mathrm{F}=154 \cdot 2$, $\mathrm{df}=12, P<0 \cdot 01)$, which was not significantly altered 

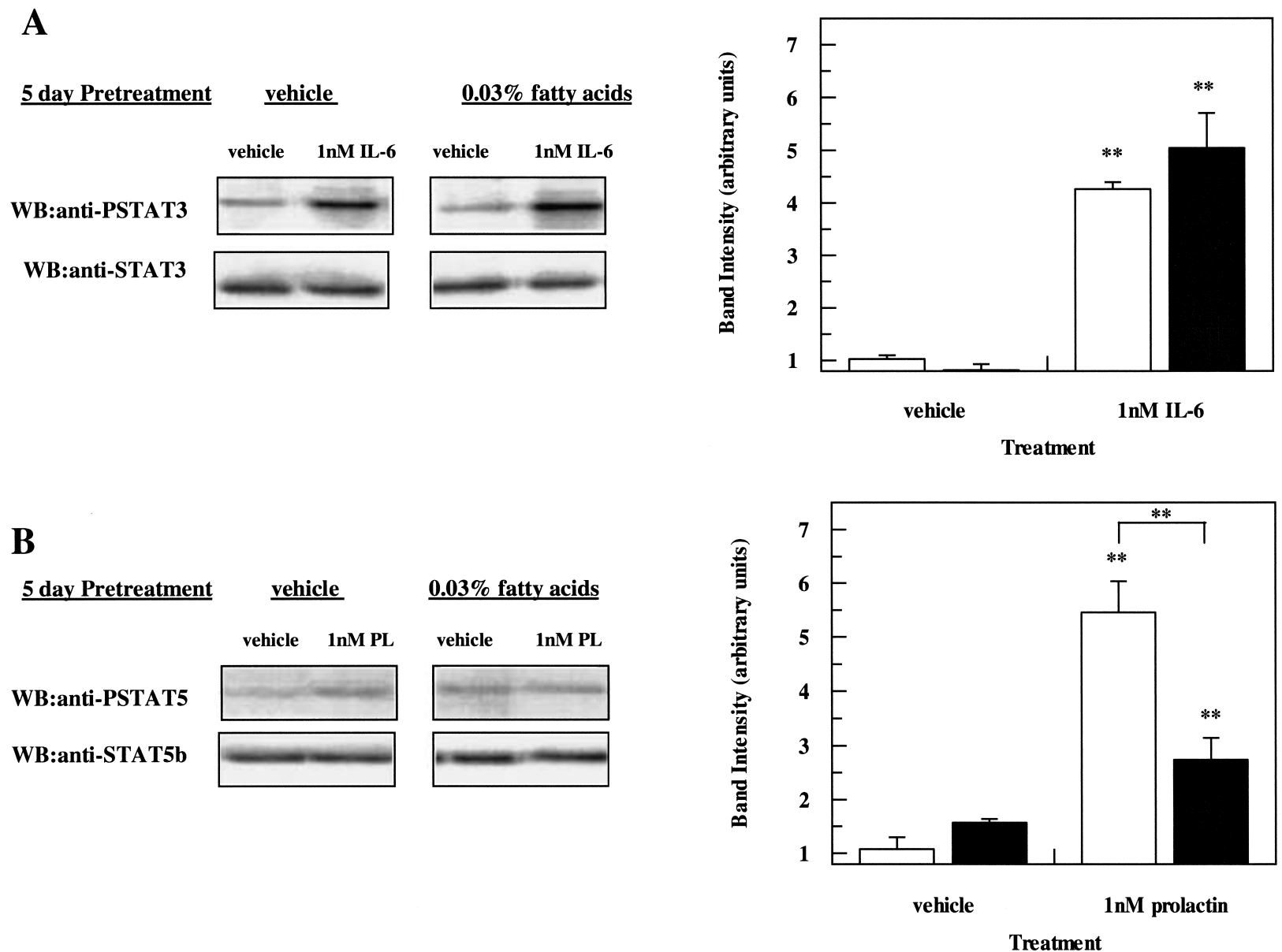

FIGURE 4. Chronic FA treatment inhibits prolactin- but not IL-6-stimulated increases in STAT tyrosine phosphorylation. BRIN-BD11 cells were treated with $1 \mathrm{nM}$ IL-6 (A) or $1 \mathrm{nM}$ prolactin (PL) (B) or vehicle for 30 min after chronic FA or vehicle treatment of cells. STAT3 (A) or STAT5 (B) immunoprecipitates Western-blotted (WB) with (A) anti-phosphoSTAT3-specific antibody (anti-PSTAT3), stripped and then reprobed with anti-STAT3 antibody or (B) anti-phosphoSTAT5-specific antibody (anti-PSTAT5), stripped and then reprobed with anti-STAT5 antibody. Phosphorylation was quantified by ECF and normalised to the levels of STAT protein present. Results are expressed as means \pm S.E.M. $(n=3)$ and are from one representative experiment $($ of three). $\square$, Vehicle; $\mathbf{\square}, 0 \cdot 03 \%$ FAs; $* *<<0 \cdot 01$.

in cells treated chronically with FAs. Prolactin has been shown to stimulate STAT5 nuclear translocation and insulin secretion in a glucose-dependent manner in INS-1 cells (Stout et al. 1997). In our study using BRIN-BD11 cells, a 30 min treatment with $1 \mathrm{nM}$ prolactin elicited a significant increase in tyrosine phosphorylation of STAT5b, after a 5 day pretreatment with either vehicle (2-way ANOVA, $\mathrm{F}=102, \mathrm{df}=11, P<0 \cdot 01)$ or FAs (2-way ANOVA, $\mathrm{F}=18.7 \mathrm{df}=11, P<0 \cdot 01)$. However, in contrast to the finding with IL-6, prolactin-stimulated STAT5b tyrosine phosphorylation was significantly attenuated in BRIN-BD11 cells after the 5 day FA treatment (3-way ANOVA, $F=14 \cdot 5, d f=22$,
$P<0 \cdot 01)$. Again, similar results were achieved, at the level of DNA binding, using EMSA (data not shown). This suggests that the effects of FAs are receptor or ligand specific and not due to different signalling strengths, as both IL-6 and prolactin produced approximately equivalent increases in STAT tyrosine phosphorylation.

\section{Effect of FA pretreatment on expression of Ob-Rb, SOCS3 and CIS}

Possible sites of action for the modulatory effects of chronic FA treatment include changes in expression 
of the functional leptin receptor and/or of inhibitors of cytokine signalling. Studies with $o b / o b$ mice and overexpression studies with $\mathrm{CHO}$ cells and RINm5F cells have suggested that levels of SOCS3 and CIS play an important role in inhibition of leptin-stimulated STAT signalling (Bjorbaek et al. 1998, Emilsson et al. 1999). Therefore, it is anticipated that FAs might prevent leptin-activation of STAT proteins, by elevating endogenous levels of SOCS3 or CIS or by raising levels of the receptor itself. In order to determine the relative quantities of $\mathrm{Ob}-\mathrm{Rb}, \mathrm{SOCS} 3$ and CIS mRNA present after chronic FA treatment, TaqMan analysis, a quantitative PCR technique, was performed. Neither an increase in SOCS3 or CIS nor a decrease in leptin-receptor expression appears to be a feature of the inhibitory effects of chronic FA treatment on leptin-receptor-mediated signalling in BRIN-BD11 cells. As there was no change in basal levels of STAT5 tyrosine phosphorylation after chronic FA treatment, different mechanisms may underlie inhibition of leptin-stimulated STAT5 phosphorylation in acute and chronic FA studies. Further support for the fact that neither SOCS3, CIS nor tyrosine phosphatases are involved in the FA effects comes from the findings that IL-6-elicited increases in STAT3 activation were unaffected by the chronic FA pretreatment. Furthermore, merely adding FAs together with leptin for $30 \mathrm{~min}$ also inhibits leptin signalling (Fig. 2), which, as previously discussed, argues against a role for induction of STATinducible negative regulators of STAT signalling in the FA effects.

\section{Possible mechanisms of FA-mediated inhibition of leptin-stimulated STAT phosphorylation}

Hidaka et al. (1999) demonstrated that unsaturated FAs were able to interact with leptin, whereas saturated FAs had no effect. Furthermore, oleic acid $(20 \mu \mathrm{M})$ was shown to produce a small decrease in the binding of leptin, immobilised on a sensor chip, to recombinant leptin receptor. Similarly, Campbell et al. (1998) showed that reversible binding of radiolabelled FAs to leptin altered the pI and electrophoretic mobility of the protein. The question of whether FAs affect binding of leptin to its receptor in cells or in vivo has not been addressed. Moreover, in neither study was the effect of FAs on receptor-mediated downstream signalling investigated. Since oleic acid was the predominant FA in the mix used in our experiments, the possibility that interactions between FAs and leptin were responsible for the reductions in leptin signalling should be considered. Leptin receptor binding experiments were not attempted in our studies, because of the inherent difficulties in detecting binding in cell lines expressing endogenous levels of leptin receptors. The only successful reports of leptin receptor binding have been in cells overexpressing the receptor (Baumann et al. 1996). Furthermore, previously published reports of endogenous longform leptin-receptor expression and signalling in cells have not demonstrated leptin/receptor binding (Islam et al. 1997, Morton et al. 1998, 1999).

Several factors strengthen the proposal that the effects of FA treatment on leptin-receptormediated STAT signalling are not merely due to interaction with leptin. First, stimulations in cells chronically treated with FAs were performed in FA-free media containing $0 \cdot 1 \%$ BSA. It is therefore unlikely that sufficient FAs remained in the flasks, following the medium change, to interact with leptin and to alter leptin/receptor interaction. Secondly, if the binding of FAs to leptin were inhibiting receptor activation of STAT proteins, longer periods of leptin treatment or higher concentrations of leptin might diminish the FA effect and permit leptin-mediated STAT signalling. As the effects of chronic FA treatment were not reversed after the use of higher concentrations of leptin $(100 \mathrm{nM})$ or after longer periods $(60 \mathrm{~min})$ of treatment (data not shown), it seems probable that other mechanisms are central to the inhibitory effect. To our knowledge, there are no published reports demonstrating binding of FAs to prolactin, or indeed to any other known cytokines, which suggests that the FAmediated attenuation of prolactin- and leptinstimulated STAT activation had occurred via a novel mechanism.

The mechanism behind inhibition of leptinstimulated STAT activation after acute and chronic FA treatment may be different. Certainly, the 30 min treatment of cells with FAs in the presence of $0 \cdot 1 \%$ BSA compared with the 5 day treatment with FAs with $2 \%$ BSA may be expected to lead to more pronounced effects on cell signalling, because of the higher levels of free FAs present in the acute experiment. One consideration, as previously discussed, was the elevation of basal STAT5 tyrosine phosphorylation after acute, but not after chronic, FA treatment. A final argument against a role for FA/leptin interaction was the observed suppression of STAT5 tyrosine phosphorylation, to below basal levels, in response to leptin in the presence of FAs. This observation suggests that, under these conditions, some form of receptor signalling may be occurring, although such a suppression of basal STAT3 tyrosine phosphorylation was not observed. 


\section{Conclusions}

The mechanism behind the inhibition of cytokine-mediated STAT activation by FAs, therefore, probably involves an intracellular mediator upstream of STAT activation, common to both the leptin and prolactin receptor signalling pathway. In particular, acute FA treatment experiments point to a regulator of basal STAT5 tyrosine phosphorylation in the downregulation of leptin-stimulated STAT5 activation.

In summary, we have shown that a $0.03 \%$ FA cocktail inhibited leptin- and prolactin- but not IL-6-stimulated STAT activation. Although direct interaction between FAs and leptin could play a role in our observations, the data from chronic FAtreatment experiments suggest that additional mechanisms are also involved. FAs, by reducing sensitivity to leptin and prolactin, might be expected to have a negative impact on $\beta$-cell proliferation and insulin secretion.

\section{ACKNOWLEDGEMENTS}

We thank Professor Peter Flatt for the BRIN-BD11 cells, Gary Moore for his advice on TaqMan assays, and Brian Bond for help with statistical analysis. Shahid Hanif was supported by a BBSRC CASE award studentship.

\section{REFERENCES}

Al-Barazanji KA, Buckingham RE, Arch JR, Haynes A, Mossakowska DE, McBay DL, Holmes SD, McHale MT, Wand XM \& Gloger IS 1997 Effects of intracerebroventricular infusion of leptin in obese zucker rats. Obesity Research 5 387-394.

Banks AS, Davis SM, Bates SH \& Myers MG Jr 2000 Activation of downstream signals by the long form of the leptin receptor. Fournal of Biological Chemistry 275 14563-14572.

Baumann H, Morella KK, White DW, Dembski M, Bailon PS, Kim H, Lai CF \& Tartaglia LA 1996 The full-length leptin receptor has signaling capabilities of interleukin 6-type cytokine receptors. PNAS 93 8374-8378.

Bjorbaek C, Uotani S, Dasilva B \& Flier JS 1997 Divergent signaling capacities of the long and short isoforms of the leptin receptor. Fournal of Biological Chemistry 272 32686-32695.

Bjorbaek C, Elmquist JK, Frantz JD, Shoelson SE \& Flier JS 1998 Identification of socs-3 as a potential mediator of central leptin resistance. Molecular Cell 1 619-625.

Bjorbaek C, El-Haschimi K, Frantz JD \& Flier JS 1999 The role of SOCS-3 in leptin signaling and leptin resistance. Fournal of Biological Chemistry 274 30059-30065.

Campbell FM, Gordon MJ, Hoggard N \& Duttaroy AK 1998 Interaction of free fatty acids with human leptin. Biochemical and Biophysical Research Communications 247 654-658.
Carpenter LR, Farruggella TJ, Symes A, Karow ML, Yancopoulos GD \& Stahl N 1998 Enhancing leptin response by preventing sh2-containing phosphatase 2 interaction with ob receptor. PNAS 95 6061-6066.

Chen H, Charlat O, Tartaglia LA, Woolf EA, Weng X, Ellis SJ, Lakey ND, Culpepper J, Moore KJ, Breitbart RE, Duyk GM, Tepper RI \& Morgenstern JP 1996 Evidence that the diabetes gene encodes the leptin receptor-identification of a mutation in the leptin receptor gene in $\mathrm{db} / \mathrm{db}$ mice. Cell 84 491-495.

Considine RV, Sinha MK, Heiman ML, Kriauciunas A, Stephens TW, Nyce MR, Ohannesian JP, Marco CC, Mckee LJ, Bauer TL \& Caro JF 1996 Serum immunoreactive leptin concentrations in normal-weight and obese humans. New England Fournal of Medicine 334 292-295.

Emilsson V, Liu YL, Cawthorne MA, Morton NM \& Davenport M 1997 Expression of the functional leptin receptor mrna in pancreatic islets and direct inhibitory action of leptin on insulin secretion. Diabetes 46 313-316.

Emilsson V, Arch JRS, de Groot RP, Lister CA \& Cawthorne MA 1999 Leptin treatment increases suppressors of cytokine signaling in central and peripheral tissues. FEBS Letters 455 170-174.

Frederich RC, Hamann A, Anderson S, Lollmann B, Lowell BB \& Flier JS 1995 Leptin levels reflect body lipid content in mice - evidence for diet-induced resistance to leptin action. Nature Medicine 1 1311-1314.

Ghilardi N, Ziegler S, Wiestner A, Stoffel R, Heim MH \& Skoda RC 1996 Defective STAT signaling by the leptin receptor in diabetic mice. PNAS 93 6231-6235.

Heinrich PC, Behrmann I, Mullernewen G, Schaper F \& Graeve L 1998 Interleukin-6-type cytokine signalling through the gp130/jak/stat pathway. Biochemical fournal 334 297-314.

Hidaka T, Morishita T, Shimotohno KW, Endo T, Seto H \& Noguchi T 1999 Screening of microbial products modifying the action of leptin (obese gene product) by a biosensor. Fournal of Antibiotics 52 429-432.

Islam MS, Morton NM, Hansson A \& Emilsson V 1997 Rat insulinoma-derived pancreatic beta-cells express a functional leptin receptor that mediates a proliferative response. Biochemical and Biophysical Research Communications 238 851-855.

Kulkarni RN, Wang ZL, Wang RM, Hurley JD, Smith DM, Ghatei MA, Withers DJ, Gardiner JV, Bailey CJ \& Bloom SR 1997 Leptin rapidly suppresses insulin release from insulinoma cells, rat and human islets and, in vivo, in mice. Fournal of Clinical Investigation 100 2729-2736.

Lee GH, Proenca R, Montez JM, Carroll KM, Darvishzadeh JG, Lee JI \& Friedman JM 1996 Abnormal splicing of the leptin receptor in diabetic mice. Nature 379 632-635.

Lee YH, Hirose H, Ohneda M, Johnson JH, McGarry JD \& Unger RH $1994 \beta$-cell lipotoxicity in the pathogenesis of non-insulin-dependent diabetes mellitus of obese rats: impairment in adipocyte- $\beta$-cell relationships. PNAS 91 10878-10882.

Lee YH, Hirose H, Zhou Y-T, Esser V, McGarry JD \& Unger RH 1997 Increased lipogenic capacity of the islets of obese rats. Diabetes 46 408-413.

Li C \& Friedman JM 1999 Leptin receptor activation of $\mathrm{SH} 2$ domain containing protein tyrosine phosphatase 2 modulates $\mathrm{Ob}$ receptor signal transduction. PNAS $\mathbf{9 6}$ 9677-9682.

McClenaghan NH, Barnett CR, Ahsing E, Abdelwahab YH, O'Harte FPM, Yoon TW, Swanston-Flatt SK \& Flatt PR 1996 Characterization of a novel glucose-responsive insulin-secreting cell line BRIN-BD11, produced by electrofusion. Diabetes 45 1132-1140. 
McCowen KC, Chow JC \& Smith RJ 1998 Leptin signaling in the hypothalamus of normal rats in vivo. Endocrinology 139 $4442-4447$.

Milburn JL Jr, Hirose H, Lee YH, Nagasawa Y, Ogawa A, Ohneda M, BeltrandelRio H, Newgard CB, Johnson JH \& Unger RH 1995 Pancreatic $\beta$-cells in obesity. Fournal of Biological Chemistry 270 1295-1299.

Morton NM, Emilsson V, Liu YL \& Cawthorne MA 1998 Leptin action in intestinal cells. Fournal of Biological Chemistry 273 26194-26201.

Morton NM, Emilsson V, de Groot RP, Pallett AL \& Cawthorne MA 1999 Leptin signalling in pancreatic islets and clonal insulin-secreting cells. Fournal of Molecular Endocrinology 22 173-184.

Overbergh L, Valckx D, Waer M \& Mathieu C 1999 Quantification of murine cytokine mRNAs using real time quantitative Reverse Transcriptase PCR. Cytokine 4 305-312.

Roche E, Buteau J, Aniento I, Reig JA, Soria B \& Prentki M 1999 Palmitate and oleate induce the immediate-early response genes c-fos and nur-77 in the pancreatic beta-cell line INS-1. Diabetes 48 2007-2014.

Seufert J, Kieffer TJ \& Habener JF 1999 Leptin inhibits insulin gene transcription and reverses hyperinsulinemia in leptin-deficient ob/ob mice. PNAS 96 674-679.

Shimabukuro M, Koyama K, Chen GX, Wang MY, Trieu F, Lee Y, Newgard CB \& Unger RH 1997 Direct antidiabetic effect of leptin through triglyceride depletion of tissues. PNAS 94 4637-4641.

Southern C, Schulster D \& Green IC 1990 Inhibition of insulin secretion from rat islets of Langerhans by interleukin-6. An effect distinct from that of interleukin-1. Biochemical fournal 272 243-245

Starr R, Willson TA, Viney EM, Murray LJL, Rayner JR, Jenkins BJ, Gonda TJ, Alexander WS, Metcalf D, Nicola NA \& Hilton DJ 1997 A family of cytokine-inducible inhibitors of signalling. Nature 387 917-921.

Stout LE, Svensson AM \& Sorenson RL 1997 Prolactin regulation of islet-derived INS-1 cells - characteristics and immunocytochemical analysis of STAT5 translocation. Endocrinology 138 1592-1603.

Tanabe K, Okuya S, Tanizawa Y, Matsutani A \& Oka Y 1997 Leptin induces proliferation of pancreatic beta cell line
MIN6 through activation of mitogen-activated protein kinase. Biochemical and Biophysical Research Communications $241765-768$

Tartaglia LA, Dembski M, Weng X, Deng NH, Culpepper J, Devos R, Richards GJ, Campfield LA, Clark FT, Deeds J, Muir C, Sanker S, Moriarty A, Moore KJ, Smutko JS, Mays GG, Woolf EA, Monroe CA \& Tepper RI 1995 Identification and expression cloning of a leptin receptor, ob-r. Cell 83 1263-1271.

Unger RH 1995 Lipotoxicity in the pathogenesis of obesitydependent niddm - genetic and clinical implications. Diabetes $44863-870$

Vaisse C, Halaas JL, Horvath CM, Darnell JE Jr, Stoffel M \& Friedman JM 1996 Leptin activation of STAT3 in the hypothalamus of wild-type and ob/ob mice but not $\mathrm{db} / \mathrm{db}$ mice. Nature Genetics 14 95-97.

Yoshimura A, Ohkubo T, Kiguchi T, Jenkins NA, Gilbert DJ, Copeland NG, Hara T \& Miyajima A 1995 A novel cytokine-inducible gene cis encodes an $\mathrm{SH} 2$-containing protein that binds to tyrosine-phosphorylated interleukin 3 and erythropoietin receptors. EMBO Fournal 14 2816-2826.

Zhang Y, Proenca R, Maffei M, Barone M, Leopold L \& Friedman JM 1994 Positional cloning of the mouse obese gene and its human homologue. Nature 372 425-432.

Zhao AZ, Bornfeldt KE \& Beavo JA 1998 Leptin inhibits insulin secretion by activation of phosphodiesterase $3 \mathrm{~b}$. Fournal of Clinical Investigation 102 869-873.

Zhong Z, Wen ZL \& Darnell JE 1994 Stat3 - a stat family member activated by tyrosine phosphorylation in response to epidermal growth factor and interleukin-6. Science $\mathbf{2 6 4}$ 95-98.

Zhou Y-P \& Grill VE 1994 Long-term exposure of rat pancreatic islets to fatty acids inhibits glucose-induced insulin secretion and biosynthesis through a glucose fatty acid cycle. Fournal of Clinical Investigation 93 870-876.

Zhou YT, Shimabukuro M, Koyama K, Lee Y, Wang MY, Trieu F, Newgard CB \& Unger RH 1997 Induction by leptin of uncoupling protein-2 and enzymes of fatty acid oxidation. PNAS 94 6386-6390.

RECEIVED IN FINAL FORM 2 November 2000 ACCEPTED 13 November 2000 